\title{
Minimising Corruption in Bangladesh: Is this an Impossible Dream?
}

\author{
Jon S.T. Quah \\ Former Professor of Political Science, National University of Singapore
}

\section{INTRODUCTION}

In 1996, Bangladesh was ranked $51^{\text {st }}$ among the 54 countries included in Transparency International's Corruption Perceptions Index (CPI) with a score of 2.29. It was perceived five years later to be the most corrupt country on the CPI in 2001 and retained that position until 2005. Even though Bangladesh's CPI rankings and scores have improved in recent years, corruption remains a serious problem today as Bangladesh was ranked $146^{\text {th }}$ among 180 countries on the 2020 CPI with a score of $26 .{ }^{1}$ Even though the CPI has several limitations, ${ }^{2}$ it is viewed as a robust indicator because of the combination of several measures of corruption for each country. ${ }^{3}$ Why is corruption a serious problem in Bangladesh? Why is the Anti-Corruption Commission (ACC) in Bangladesh ineffective in curbing corruption? Will Bangladesh be able to overcome its contextual constraints and chronic lack of political will to minimise corruption?

This article addresses these questions by contending that the various governments in Bangladesh fail to curb corruption effectively because of their weak political will to address the causes of corruption and its unfavourable policy context. It concludes that corruption in Bangladesh can only be minimised if the government has the strong political will to address the causes of corruption and to enhance the ACC's effectiveness as an independent watchdog by providing it with the necessary legal powers, budget, personnel and autonomy to enforce the anti-corruption laws impartially.

\section{BANGLADESH'S UNFAVOURABLE POLICY CONTEXT}

The policy context refers to the geographical, historical, economic, demographic and political aspects of a country's environment that influence the nature and style of the formulation and implementation of public policies. This factor is important because it promotes or hinders the incumbent government's anti-corruption efforts, depending on

1 Transparency International, Corruption Perceptions Index 2020. From 1995-2011, the CPI scores range from 0 (highly corrupt) to 10 (very clean). However, from 2012, the CPI scores vary from 0 (highly corrupt) to 100 (very clean).

2 See Fredrik Galtung, 'Measuring the Immeasurable: Boundaries and Functions of (Macro) Corruption Indices' in Charles Sampford, Fredrik Galtung, Arthur Shacklock and Carmel Connors (eds), Measuring Corruption (Ashgate 2006) 101-130 and Kilkon Ko and Ananya Samajdar, 'Evaluation of International Corruption Indexes: Should We Believe Them or Not?' (2010) 47 Social Science Journal 508-540.

3 Thomas D. Lancaster and Gabriella R. Montinola, 'Toward a Methodology for the Comparative Study of Political Corruption' (1997) 27 Crime, Law and Social Change 185-206. 
whether the contextual factors are conducive or hostile to the implementation of the anti-corruption measures. ${ }^{4}$

Bangladesh is an "impaired" state because "wayward politics, poor governance and the vulnerability of the economy have produced a state that is feeble and fragmented." It is ranked $39^{\text {th }}$ among 178 countries on the Fragile States Index in 2020 with a "high warning" score of 85.7. ${ }^{6}$ Bangladesh's poor governance is also reflected in its performance on the World Bank's six governance indicators from 2004 to 2019. Table 1 shows that its low level of governance has increased from a total percentile rank of 87.84 in 2004 to 134.46 in 2011 but declined again to 125.5 in 2019. Voice and accountability has remained at the same level (27.59 to 27.09) in Bangladesh but the percentile ranks for the other five indicators have improved with the most significant improvements for the control of corruption $(+14.89)$ and rule of law $(+12.09)$, followed by moderate increases for political stability and absence of violence $(+5.05)$, government effectiveness (+3.36) and regulatory quality (+3.06). Bangladesh's weakest score on political stability and absence of violence is manifested in the several changes in government between the Bangladesh Nationalist Party (BNP) led by Khaleda Zia and the Awami League (AL) led by Sheikh Hasina since 1991. The AntiCorruption Evidence Research Consortium concluded in October 2017 that Bangladesh's "overall political context remains vulnerable" because "changes in the overall political settlement constitute risk factors" which hinder the implementation of anti-corruption efforts. ${ }^{7}$

Table 1: Bangladesh's Low Levels of Governance (2004-2019) ${ }^{8}$

\begin{tabular}{|c|c|c|c|c|c|c|}
\hline \multirow{2}{*}{$\begin{array}{l}\text { World Bank's } \\
\text { governance } \\
\text { indicators }^{\text {a }}\end{array}$} & \multicolumn{2}{|l|}{2004} & \multicolumn{2}{|l|}{2011} & \multicolumn{2}{|l|}{2019} \\
\hline & Score $^{b}$ & $\begin{array}{l}\text { Percentile } \\
\text { rank }\end{array}$ & Score & $\begin{array}{l}\text { Percentile } \\
\text { rank }\end{array}$ & Score & $\begin{array}{l}\text { Percentile } \\
\text { rank }\end{array}$ \\
\hline $\begin{array}{l}\text { Voice and } \\
\text { accountability }\end{array}$ & -0.67 & 27.88 & -0.32 & 36.15 & -0.72 & 27.09 \\
\hline $\begin{array}{l}\text { Political stability and } \\
\text { absence of violence }\end{array}$ & -1.36 & 10.19 & -1.40 & 9.00 & -0.92 & 15.24 \\
\hline $\begin{array}{l}\text { Government } \\
\text { Effectiveness }\end{array}$ & -0.82 & 20.20 & -0.76 & 24.64 & -0.74 & 23.56 \\
\hline $\begin{array}{l}\text { Regulatory } \\
\text { quality }\end{array}$ & -1.13 & 12.32 & -0.81 & 22.75 & -0.93 & 15.38 \\
\hline Rule of law & -1.02 & 15.79 & -0.73 & 27.70 & -0.64 & 27.88 \\
\hline $\begin{array}{l}\text { Control of } \\
\text { corruption }\end{array}$ & -1.50 & 1.46 & -1.09 & 14.22 & -0.99 & 16.35 \\
\hline $\begin{array}{l}\text { Total percentile } \\
\text { rank }^{\text {c }}\end{array}$ & NA & 87.84 & NA & 134.46 & NA & 125.5 \\
\hline
\end{tabular}

4 Jon S.T. Quah, Curbing Corruption in Asian Countries: An Impossible Dream? (Emerald Group Publishing 2011) 30.

5 Habib Zafarullah and Redwanur Rahman, 'The Impaired State: Assessing State Capacity and Governance in Bangladesh' (2008) 21 International Journal of Public Sector Management 749.

6 Fund for Peace, Fragile States Index Annual Report 2020 (2020) 7.

7 Anti-Corruption Evidence Research Consortium, 'Anti-Corruption in Bangladesh: Towards Feasible Governance Improvements' (2017) School of Oriental and African Studies, University of London Briefing Paper 003, 4.

8 World Bank 'Worldwide Governance Indicators, 2004-2019' <https://info.worldbank.org/governance/wgi/Home/Reports> accessed 4 November 2020.

Page 96 
Notes: a For the definitions of these indicators, see Daniel Kaufmann, Aart Kraay and Massimo Mastruzzi, 'Governance Matters VIII: Aggregate and Individual Governance Indicators 1996-2008' (2009) World Bank Policy Research Working Paper 4978, 6.

$\mathrm{b}$ The governance score ranges from -2.5 to +2.5 .

${ }^{\mathrm{c}}$ The total percentile rank ranges from 0 to 600 for the six indicators.

Apart from its poor governance, four aspects of Bangladesh's policy context also hinder its government's effectiveness in combating corruption. First, Bangladesh has a land area of $130,170 \mathrm{sq}$. $\mathrm{km}$ and its population of $163,046,160$ persons is the eighth largest in the world with a population density of 1,252 persons per sq. $\mathrm{km} .{ }^{9}$ This means that the ACC faces the tremendous challenge of enforcing the anti-corruption laws across a vast territory and investigating the 70,464 corruption complaints it received from the population from 2014-2018. ${ }^{10}$

As Bangladesh was a British colony as part of India until August 1947 and before it attained independence from Pakistan in March 1971, the origins of the Public Service Commission (PSC) established in 1972 can be traced to the PSC formed by the British in India in 1926. ${ }^{11}$ The PSC is the adapted version of the Civil Service Commission in Britain that introduced meritocracy to India and other British colonies, including Singapore and Hong Kong, by recruiting and promoting civil servants on the basis of merit instead of patronage. ${ }^{12}$ The bureaucracy in Bangladesh has retained many features of British colonial administration but it is now afflicted by "increasing politicization." 13 More importantly, unlike Singapore and Hong Kong, the PSC in Bangladesh has failed to institutionalise the tradition of meritocracy as a World Bank survey of 821 senior Bangladeshi officials conducted in 1999 found that one-third of the respondents believed that recruitment to the civil service was based on patronage instead of merit and half of them indicated that these patronage appointments were influenced by personal and family connections. ${ }^{14}$ As will be shown in the next section, the importance of kinship ties and tadbir has enhanced the influence of nepotism in the recruitment of civil servants. In other words, the absence of meritocracy in the recruitment and promotion of civil servants in Bangladesh has hindered the ACC's efforts in combating corruption.

The third aspect of the policy context that influences the ACC's ability to curb corruption is that Bangladesh remains a lower-middle income country with a GDP per capita of US\$1,855.70 in 2019 even though its poverty rate has been reduced from 48.9

\footnotetext{
9 World Bank, 'Land area (sq. km)' (2019) <https://data.worldbank.org/indicator/ AG.LND.TOTL.K2> accessed 1 September 2020 and World Bank, 'Population, total' (2020) <https://data.world bank.org/indicator/SP.POP.TOTL> accessed 1 September 2020. 
per cent to 24.5 per cent from 2000 to $2016 .{ }^{15}$ As combating corruption is expensive because the government has to provide the ACC with an adequate budget and sufficient personnel, it cannot afford to allocate the resources needed without foreign financial and technical assistance or to pay adequate salaries to civil servants to prevent petty corruption.

Finally, Bangladesh's low percentile ranks for government effectiveness and regulatory quality from 2004-2019 (see Table 1) are reflected in the high incidence of red tape in the public bureaucracy. As will be shown below, Bangladesh's $176^{\text {th }}$ ranking among 190 countries on the World Bank's ease of doing business rank in 2019 confirms that red tape is a serious problem that increases the opportunities for bureaucratic corruption. ${ }^{16}$

\section{CAUSES OF CORRUPTION IN BANGLADESH}

To combat corruption effectively, policy-makers in Bangladesh must introduce appropriate reforms to address its causes instead of its symptoms. ${ }^{17}$ In his pioneering comparative study of anti-corruption measures in Hong Kong, India and Indonesia, Leslie Palmier identified three important causes of corruption: low salaries of civil servants; ample opportunities for corruption provided by excessive regulations and red tape; and the low probability of detecting and punishing corruption offenders. His hypothesis was: "At one extreme, with few opportunities, good salaries, and effective policing, corruption will be minimal; at the other, with many opportunities, poor salaries, and weak policing, it will be considerable." 18 Apart from Palmier's three causes, this section also analyses the impact of cultural values and practices on corruption in Bangladesh.

\section{A. Low salaries of civil servants}

Low salaries contribute to corruption because "when civil service pay is too low, civil servants may be obliged to use their positions to collect bribes as a way of making ends meet, particularly when the expected cost of being caught is low." ${ }^{19}$ A comparative study of civil service compensation in South Asian countries found that corruption was "an unsavoury response" to the "falling or low real salary scales" and became widespread and viewed as "inevitable and incurable by the public." For example, the salaries of Bangladeshi civil servants decreased by 87 per cent for senior positions to 43 per cent for the lowest positions since $1971 .^{20}$ The salaries of public officials in

15 World Bank, 'GDP per capita (current US\$)' (2019) < https://data.worldbank.org/indicator /NY.GDP.PCAP.CD> accessed 1 September 2020 and World Bank, Bangladesh Poverty Assessment: Facing Old and New Frontiers in Poverty Reduction (2019) 22.

16 World Bank, Doing Business 2019: Training for Reform (2019) 4.

17 For a comprehensive analysis of the causes of corruption, see Daniel Triesman, 'What have we learned about the Causes of Corruption from ten years of Cross-National Empirical Research?' (2007) 10 Annual Review of Political Science 211-244.

18 Leslie Palmier, The Control of Bureaucratic Corruption: Case Studies in Asia (Allied Publishers 1985) 271-272.

19 Paolo Mauro, Why Worry about Corruption? (International Monetary Fund 1997) 5.

20 David C.E. Chew, Civil Service Pay in South Asia (International Labour Organisation 1992) 2, 101.

Page $\mid 98$ 
Bangladesh are still low even though they have increased from 2009 to 2019. Table 2 shows that the basic monthly salaries in 2019 range from Tk 8,250 (US\$97) for Grade 20 to Tk 78,000 (US\$920) for Grade 1. The basic monthly salaries of political office holders vary from Tk 92,000 (US\$1,086) for a State Minister to Tk 120,000 (US\$1,416) for the President.

Table 2: Bangladesh Government Salary Scale 2019 ${ }^{21}$

\begin{tabular}{|c|c|c|}
\hline National Grade & Basic Salary & Entry and Position \\
\hline 20 & Tk 8,250 & Class 5 to Class 8 \\
\hline 19 & $\mathrm{Tk} 8,500$ & \\
\hline 18 & Tk 8,800 & SSC/HSC Equivalent \\
\hline 17 & Tk 9,000 & \\
\hline 16 & Tk 9,300 & Office Assistant \\
\hline 15 & $\operatorname{Tk} 9,700$ & Assistant Teacher \\
\hline 14 & Tk 10,200 & \\
\hline 13 & Tk 11,000 & \\
\hline 12 & Tk 11,300 & \\
\hline 11 & Tk 12,000 & \\
\hline 10 & Tk 16,000 & \\
\hline 9 & Tk 22,000 & BCS Officer, Assistant Secretary \\
\hline 8 & Tk 23,000 & \\
\hline 7 & Tk 29,000 & Senior Assistant Secretary \\
\hline 6 & Tk 35,500 & Deputy Secretary \\
\hline 5 & Tk 43,000 & Joint Secretary \\
\hline 4 & Tk 50,000 & Additional Secretary \\
\hline 3 & Tk 56,000 & Member of Parliament \\
\hline 2 & Tk 66,000 & \\
\hline \multirow[t]{6}{*}{1} & Tk 78,000 & Secretary, Major General \\
\hline & Tk 82,000 & Senior Secretary, Lt. General \\
\hline & Tk 86,000 & $\begin{array}{l}\text { Chiefs of Armed Forces } \\
\text { Principal Secretary } \\
\text { Cabinet Division Secretary }\end{array}$ \\
\hline & Tk 92,000 & State Minister \\
\hline & Tk 105,000 & Leader of the Opposition \\
\hline & Tk 105,000 & Minister \\
\hline
\end{tabular}

21 "Bangladesh Government Pay Scale 2019" < https://bangla.bdnewsnet.com/bd/jobnews/bangladeshgovernment-pay-scale-bd-2019/> accessed 4 November 2020. I would like to thank Professor Sumaiya Khair for providing me with this salary scale. 
Dhaka University Law Journal, Centennial Special Issue, Vol. 32(1)

\begin{tabular}{|l|l|l|}
\hline & Tk 110,000 & Chief Minister \\
\hline & Tk 112,000 & Speaker of Parliament \\
\hline & Tk 115,000 & Prime Minister \\
\hline & Tk 120,000 & President \\
\hline
\end{tabular}

Note: The exchange rate was US\$1 = Tk 84.75 on 4 November 2020.

\section{B. Red tape enhances opportunities for corruption}

Red tape refers to those "bureaucratic procedures characterised by mechanical adherence to regulations, excessive formality, and attention to routine, and the compilation of large amounts of extraneous information resulting in prolonged delay or inaction." ${ }^{22}$ Civil servants are tempted by the "opportunities to sell their official discretion and information" and the "opportunities to extort payments" as "permits can be delayed, licences held up, deliberations protracted, proceedings prolonged, unless rewards are offered." ${ }^{23}$ Red tape increases the opportunities for corruption by providing civil servants with an excuse to extort bribes from citizens who are willing to pay "speed money" to cut red tape and reduce delay by expediting their applications for licences or permits.

The World Bank's annual survey on the ease of doing business in 190 countries is a measure of the extent of red tape as it is easier to conduct business in countries with little or no red tape. Table 3 shows that Bangladesh has the most serious problem of red tape among the eight South Asian countries because it is ranked $176^{\text {th }}$ among 190 countries for the ease of doing business in 2019. For example, it takes 273.5 days to obtain a construction permit in Bangladesh compared to 87 days in Sri Lanka. Even Bhutan, which has a higher CPI score than Bangladesh, suffers from red tape because it requires 150 days to get a construction permit.

Table 3: Red Tape and Corruption in South Asian Countries 2019 ${ }^{24}$

\begin{tabular}{|l|l|l|c|l|}
\hline \multirow{2}{*}{ Country } & \multirow{2}{*}{$\begin{array}{l}\text { Ease of doing } \\
\text { business rank }\end{array}$} & \multicolumn{2}{|l|}{ Dealing with construction permits } & CPI rank and \\
\cline { 3 - 4 } & & No. of procedures & No. of days & \\
\hline India & $77^{\text {th }}$ & 17.9 & 94.8 & $80^{\text {th }}(41)$ \\
\hline Bhutan & $81^{\text {st }}$ & 21 & 150 & $25^{\text {th }}(68)$ \\
\hline Sri Lanka & $100^{\text {th }}$ & 13 & 87 & $93^{\text {rd }}(38)$ \\
\hline Nepal & $110^{\text {th }}$ & 12 & 117 & $113^{\text {th }}(34)$ \\
\hline Pakistan & $136^{\text {th }}$ & 18.7 & 262.8 & $120^{\text {th }}(32)$ \\
\hline Maldives & $139^{\text {th }}$ & 10 & 140 & $130^{\text {th }}(29)$ \\
\hline Afghanistan & $167^{\text {th }}$ & 13 & 199 & $173^{\text {rd }}(16)$ \\
\hline Bangladesh & $176^{\text {th }}$ & 15.8 & 273.5 & $146^{\text {th }}(26)$ \\
\hline
\end{tabular}

22 Ralph C. Chandler and Jack C. Plano, The Public Administration Dictionary (2 $2^{\text {nd }}$ ed., ABC-Clio 1988) 233.

23 Herbert Kaufman, Red Tape: Its Origins, Uses, and Abuses (Brookings Institution 1977) 51-53.

${ }^{24}$ World Bank, Doing Business 2019 (2019) and Transparency International, Corruption Perceptions Index 2019 (2020).

Page $\mid 100$ 


\section{Low probability of detection and punishment}

Individuals found guilty of corruption offences should be punished according to the law. However, in reality, the probability of detecting and punishing corrupt offenders varies in Asian countries. Corruption is not a serious problem in Singapore or Hong Kong where it is perceived as a "high risk, low reward" activity as those involved in corruption are likely to be caught and severely punished. On the other hand, corruption thrives in Bangladesh and the Philippines, where the public perceives corruption as a "low risk, high reward" activity because corrupt offenders are unlikely to be detected and punished. ${ }^{25}$

A comparative study of three South Asian countries found that "official punitive action has seldom been taken against corrupt officials" in spite of the large number of corruption reports. An analysis of corruption reports in the Bangladesh Observer in Dhaka, the Times of India in Mumbai, and the Daily News in Colombo, from November to December 1996, identified 119 cases in India, 91 cases in Sri Lanka, and 77 cases in Bangladesh. However, only 18 cases (15 per cent) in India resulted in official punitive action, followed by eight cases (10 per cent) in Bangladesh, and four cases (4 per cent) in Sri Lanka. Ahmad and Brookins concluded that the lenient punishment of corrupt offenders in the three countries had contributed to the spread of corruption into new areas and could not be curbed unless corrupt individuals were held accountable for their misconduct. ${ }^{26}$

Table 4: Disposal of Corruption Cases by the ACC (2012-2018) ${ }^{27}$

\begin{tabular}{|l|l|l|l|l|l|l|}
\hline Year & $\begin{array}{l}\text { No. of } \\
\text { cases of } \\
\text { on-going } \\
\text { trials }\end{array}$ & $\begin{array}{l}\text { Pending } \\
\text { cases in } \\
\text { higher } \\
\text { courts }\end{array}$ & $\begin{array}{l}\text { Total no. } \\
\text { of cases } \\
\text { under } \\
\text { trial }\end{array}$ & $\begin{array}{l}\text { No._of of } \\
\text { convictions }\end{array}$ & $\begin{array}{l}\text { No. ofquittals } \\
\text { acf }\end{array}$ & $\begin{array}{l}\text { Total no. of } \\
\text { cases } \\
\text { disposed }\end{array}$ \\
\hline 2012 & 1,605 & 411 & 2,016 & $42(31.8 \%)$ & $90(68.2 \%)$ & $132(6.5 \%)$ \\
\hline 2013 & 2,030 & 350 & 2,380 & $67(36.6 \%)$ & $116(63.4 \%)$ & $183(7.7 \%)$ \\
\hline 2014 & 2,310 & 414 & 2,724 & $73(45.9 \%)$ & $86(54.1 \%)$ & $159(5.8 \%)$ \\
\hline 2015 & 2,660 & 437 & 3,097 & $69(36.7 \%)$ & $119(63.3 \%)$ & $188(6.1 \%)$ \\
\hline 2016 & 2,240 & 400 & 2,640 & $116(54.2 \%)$ & $98(45.8 \%)$ & $214(8.1 \%)$ \\
\hline 2017 & 2,446 & 357 & 2,803 & $161(67.9 \%)$ & $76(32.1 \%)$ & $237(8.5 \%)$ \\
\hline 2018 & 2,494 & 306 & 2,800 & $131(62.7 \%)$ & $78(37.3 \%)$ & $209(7.5 \%)$ \\
\hline Total & 15,785 & 2,675 & 18,460 & $659(49.8 \%)$ & $663(50.2 \%)$ & $1,322(7.2 \%)$ \\
\hline
\end{tabular}

${ }^{25}$ Quah (n 4) 18.

${ }^{26}$ Naved Ahmad and Oscar T. Brookins, 'On Corruption and Countervailing Actions in three South Asian Nations' (2004) 7 Journal of Economic Policy Reform 24, 29.

${ }^{27}$ Salahuddin Aminuzzaman, Shahzada M. Akram and Shammi Laila Islam, Anti-Corruption Agency Strengthening Initiative: Assessment of Bangladesh Anti-Corruption Agency 2016 (Transparency International Bangladesh 2016) 36; Bangladesh ACC, Annual Report 2016 (2017) 32; Bangladesh ACC, Annual Report 2017 (2018) 37; and Bangladesh ACC, Annual Report 2018 (2019) 34. 
Table 4 confirms that corruption is perceived as a low risk, high reward activity in Bangladesh because only 1,322 cases ( 7.2 per cent) of the 18,460 cases under trial were disposed by the ACC during 2012-2018. More importantly, only 659 (49.8 per cent) of the disposed cases resulted in convictions and 663 cases (50.2 per cent) were acquitted. It should also be noted that the ACC's conviction rate has increased from 46 per cent in 2014 to 63 per cent in 2018, with an average conviction rate of 54 per cent during this period. ${ }^{28}$

\section{Cultural values and practices}

Culture seemingly contributes to corruption in Bangladesh when cultural practices like gift-giving influence individuals to give and receive bribes. ${ }^{29}$ Apart from promoting reciprocity in social relations, gift-giving in Bangladesh encourages bribery among civil servants to accept gifts by businessmen wishing to cut red tape to expedite the issuance of licences. The social tradition of gift-giving in Asian countries, including Bangladesh, enables poorly paid civil servants to solicit bribes directly or indirectly. The culture of corruption in the form of money, gifts and privileges is "deeply-rooted in the inherited administrative culture" of Bangladesh. ${ }^{30}$

The important cultural practice of tadbir or the process of personal lobbying has been attributed to Bangladesh's hierarchical and kinship-based social structure. Tadbir is "a pathological peculiarity of Bangladeshi administrative culture" and promotes corruption by breaking or bending existing rules, norms and practices. ${ }^{31}$ Indeed, tadbir is the preferred method employed by businessmen in Bangladesh to obtain a personal exemption from an existing policy. Access to the bureaucracy is achieved by means of "school ties, kinship, social contact, job offers, and the payment of small gifts, cash, or goods and supplies." Consequently, public policies in Bangladesh are "riddled with a large number of exceptions and exemptions" and policies are frequently modified to accommodate the needs and interests of a prominent person's relatives. This means that "every policy can be manipulated to suit the needs of any individual who has the appropriate contacts and can pay the allotted fee." 32

Tadbir is a common practice in Bangladeshi administrative culture because those civil servants who are tadbir-friendly are viewed positively while their colleagues who refuse to entertain tadbir requests are despised by friends, relatives, senior bureaucrats and ministers. For example, officers on special duty who are waiting for a placement are not posted without tadbir because civil servants only take action by moving files

28 Bangladesh ACC, Annual Report 2017 (2018) 38 and Bangladesh ACC, Annual Report 2018 (2019) 34.

29 For two excellent analyses of the impact of culture on corruption, see Gerald E. Caiden, 'Culture and Corruption' (2012) 15 Public Administration and Policy, 93-128 and Peter Larmour, Interpreting Corruption: Culture and Politics in the Pacific Islands (University of Hawai'i Press 2012).

30 Sk. Tawfique M. Haque and Sheikh Noor Mohammad, 'Administrative Culture and Incidence of Corruption in Bangladesh: A Search for the Potential Linkage' (2013) 36 International Journal of Public Administration 998.

31 Ibid, 1000.

32 Stanley A. Kochanek, Patron-Client Politics and Business in Bangladesh (Sage Publications 1993) 251-268.

Page | 102 
or declaring files to be missing with tadbir. ${ }^{33}$ Bangladesh's collectivist society with its emphasis on family loyalty, kinship ties and nepotism, encourages corruption because the "immediate and extended families of the political leaders and senior civil servants are involved in the tadbir game, rule-breaking, and shady wheeling and dealing." Furthermore, the high degree of uncertainty avoidance among Bangladeshi civil servants results in the production of "voluminous rules, regulations, and procedures" that encourages corruption, favouritism and nepotism among them. ${ }^{34}$

\section{COMBATING CORRUPTION BANGLADESHI-STYLE}

An anti-corruption agency (ACA) is a specialised organisation created by a government as a mechanism for ensuring horizontal accountability ${ }^{35}$ by minimising corruption in the country. There are two types of ACAs in Asian countries, depending on the scope of their functions: Type A ACAs that focus exclusively on the performance of anti-corruption functions; and Type B ACAs that perform both anticorruption and non-corruption-related functions. ${ }^{36}$ When a government decides to establish an ACA, it has to make three decisions. First, it should learn from the adverse experiences of Afghanistan, China, India, Pakistan, Philippines, Taiwan and Vietnam and avoid relying on multiple ACAs. The second decision that the government should make is to follow the examples of Singapore and Hong Kong and establish a Type A ACA rather than a Type B ACA. Thirdly, the government has to decide what role the Type A ACA that it has created should play. Should the Type A ACA be an independent watchdog, attack dog or paper tiger?

As a former British colony which was part of India until 1947 and Pakistan until 1971, Bangladesh inherited the anti-corruption measures introduced by the British colonial government. Corruption was made an offence in the Indian Penal Code in 1860 as section 161 specified that the punishment for corruption was imprisonment for three years and/or a fine. ${ }^{37}$ The Prevention of Corruption Act (PCA) became the first anticorruption law in India in March 1947 by incorporating relevant sections of the Indian Penal Code and increasing the penalty for corruption offences from one to seven years and/or a fine. ${ }^{38}$

In 1944, the Enforcement Branch was formed in the Police Department to combat corruption. With the enactment of the PCA in 1947, the police were responsible for investigating corruption offences. As the Police Department was ineffective in curbing

33 Haque and Mohammad (n 30) 1000-1001.

34 Ibid, 1005.

35 Guillermo O'Donnell defines horizontal accountability as "the existence of state agencies that are legally enabled and empowered, and factually willing and able, to take actions that span from routine oversight to criminal sanctions or impeachment in relation to actions or omissions by other agents or agencies of the state that may be qualified as unlawful." See Guillermo O'Donnell, 'Horizontal Accountability in New Democracies' in Andreas Schedler, Larry Diamond and Marc F. Plattner (eds), The Self-Restraining State: Power and Accountability in New Democracies (Lynne Rienner 1999) 38. Jon S.T. Quah, Combating Asian Corruption: Enhancing the Effectiveness of Anti-Corruption Agencies (Carey School of Law, University of Maryland 2017) 7.

37 L. Michael Hager, 'Bureaucratic Corruption in India: Legal Control of Maladministration' (1973) 6 Comparative Political Studies 204-205.

38 Quah (n 4) 93. 
corruption, it was replaced by the Bureau of Anti-Corruption (BAC), which was established as the first Type A ACA in Bangladesh with the enactment of the AntiCorruption Act in $1957 .{ }^{39}$ However, the BAC was also ineffective because it was "a toothless organisation lacking adequate authority" to perform its anti-corruption functions effectively. ${ }^{40}$ The BAC's weak capacity resulted from its inefficiency, political patronage, inefficient public prosecutors, dearth of witnesses, and political interference in its work. ${ }^{41}$ The BAC's failure to curb corruption led to its replacement by the ACC, which was established on 21 November 2004 with the enactment of the Anti-Commission Act of 2004 (Act No. V of 2004).

Bangladesh has followed the examples of Singapore and Hong Kong and established the ACC as a Type A ACA to enforce the ACC Act of $2004 .{ }^{42}$ Article 17 of this Act identifies these functions of the ACC:

1. Investigating corruption complaints received or initiated by itself;

2. Approving the lodging of first information reports (FIRs) and sanctioning the submission of charge sheets or final reports on the basis of enquiry and investigation;

3. Investigating cases of money laundering according to the Money Laundering Prevention Act of 2012;

4. Making recommendations to the President on: (a) reviewing systems to prevent corruption; (b) preparing research studies for enhancing corruption prevention; (c) preparing a priority list based on the research findings; and (d) identifying the sources of corruption in Bangladesh and initiating appropriate measures;

5. Organising seminars, symposia and workshops to enhance public awareness of the consequences of corruption; and

6. Performing other duties imposed on it under the law to curb corruption.

The ACC's current establishment has 2,146 positions but its actual strength in 2018 is 871 personnel because it has 1,275 vacancies (59.4 per cent) ${ }^{43}$ This means that the ACC's ability to staff only 40.6 per cent of its established positions constitutes a serious constraint on its effectiveness. The annual budget that the ACC receives from the government has increased by more than three times from Tk 298.194 million (US $\$ 3.5$ million) in 2010 to Tk 944.767 million (US\$11.3 million) in $2017 .{ }^{44}$

39 Golam Shahriar Chowdhury, 'Country Report: Bangladesh' Resource Material Series No. 71 (UNAFEI 2007) 103.

40 Mohammad Ehsan, 'When Implementation Fails: The Case of Anti-Corruption Commission (ACC) in Bangladesh' (2006) 28 Asian Affairs 50.

41 A.M.M. Shawkat Ali, Bangladesh Civil Service: A Political-Administrative Perspective (Dhaka University Press 2004) 202.

42 The text of the ACC Act of 2004 is available at <https://www.oecd.org/site/adboecdanticorruptioninitiative/46812498.pdf> accessed 1 September 2020.

43 Bangladesh ACC, Annual Report 2018 (2019) 81.

44 Salahuddin Aminuzzaman and Sumaiya Khair, National Integrity System Assessment Bangladesh 2014 (Transparency International Bangladesh 2014) 176; Bangladesh ACC, Annual Report 2017 (2018) 84; and Bangladesh ACC, Annual Report 2018 (2019) 84.

Page | 104 


\section{EXPLAINING THE ACC'S INEFFECTIVENESS}

\section{A. Lack of political will}

However, after the ACC's establishment as a Type A ACA in Bangladesh, it has not performed the role of an independent watchdog like Singapore's Corrupt Practices Investigation Bureau (CPIB) or Hong Kong's Independent Commission Against Corruption (ICAC) because of the lack of political will of the governments during the past 16 years. Political will refers to the sustained commitment of political leaders to implement anti-corruption policies and programmes to address the causes of corruption in the country. ${ }^{45}$

Table 5: Per Capita Expenditures and Staff-Population Ratios of Four Asian AntiCorruption Agencies in 2016

\begin{tabular}{|l|l|l|l|l|}
\hline $\begin{array}{l}\text { Anti-Corruption } \\
\text { Agency }\end{array}$ & $\begin{array}{l}\text { Budget } \\
\text { (in millions) }\end{array}$ & Personnel & $\begin{array}{l}\text { Per capita } \\
\text { expenditure }\end{array}$ & $\begin{array}{l}\text { Staff-popula- } \\
\text { tion ratio }\end{array}$ \\
\hline Hong Kong ICAC & US\$130.50 & 1,369 & US\$17.77 & $1: 5,366$ \\
\hline Singapore CPIB & US\$28.68 & 232 & US\$5.12 & $1: 24,169$ \\
\hline Bhutan ACC & US\$1.37 & 85 & US $\$ 1.71$ & $1: 9,385$ \\
\hline Bangladesh ACC & US\$10.40 & 960 & US $\$ 0.64$ & $1: 169,741$ \\
\hline
\end{tabular}

Source: Compiled and calculated by the author from the data on the budgets and personnel in 2016 of the four ACAs from their annual reports and national budgets.

As combating corruption is expensive, the ACC needs sufficient budget and personnel to enforce the anti-corruption laws impartially. A World Bank study of the effectiveness of 50 ACAs found that as "political will and commitment are the cornerstone of every successful anti-corruption effort" their governments' "allocation of limited resources for ACA activities" signals their lack of "genuine commitment to the ACA's mission." 46 The weak political will of the Bangladeshi government to combat corruption is reflected in the ACC's low per capita expenditure and its unfavourable staff-population ratio. ${ }^{47}$ Table 5 confirms that the per capita expenditures of Hong Kong's ICAC, Singapore's CPIB and Bhutan's ACC are much higher than the Bangladesh ACC's per capita expenditure of US\$0.64 and unfavourable staffpopulation ratio of 1:169,741. Indeed, the ACC's low per capita expenditure, its highly unfavourable staff-population ratio and its 59.4 per cent vacancies confirm that it is a

45 Quah (n 36) 64.

46 Francesca Recanatini, 'Anti-Corruption Authorities: An Effective Tool to Curb Corruption?' in Susan Rose-Ackerman and Tina Soreide (eds), International Handbook on the Economics of Corruption Vol. 2 (Edward Elgar 2011) 549, 565.

47 The ACC's per capita expenditure refers to its budget for a year divided by Bangladesh's population for the same year. The ACC's staff-population ratio refers to Bangladesh's population divided by the number of its personnel for the same year. See Jon S.T. Quah, 'Benchmarking for Excellence: A Comparative Analysis of Seven Asian Anti-Corruption Agencies' (2009) 31 Asia Pacific Journal of Public Administration 182. 
paper tiger because it lacks the necessary resources to function effectively as an independent watchdog.

\section{B. Inheriting the BAC's role as an attack dog}

The BAC was highly politicised and used by the various governments as "a political tool to harass the opposition." Almost 200 corruption charges were filed against political leaders and members of parliament (MPs) during 1991-2004. After assuming power in 2001, the BNP government withdrew the 69 corruption cases filed by the BAC against its ministers, MPs and leaders during the AL administration of 19962001. In December 2001, the BAC filed corruption charges against former prime minister Sheik Hasina and six officials for misappropriating US\$120.69 million in the purchase of eight MIG-29 jet fighter planes from Russia. ${ }^{48}$ This means that the "standard practice" of the ruling party, whether AL or BNP, is to use the BAC to lodge complaints against the previous government, which means that the ruling party is "always immune from prosecution as long as they remain in power." ${ }^{49}$ In the same vein, another observer has accused the BAC of engaging in "political witch-hunts" because it only investigated corruption cases after getting approval from the prime minister's office. ${ }^{50}$

Regrettably, the ACC has failed to learn from the BAC's weaknesses for two reasons. First, the ACC was not formed because of the incumbent government's commitment to combating corruption in Bangladesh but in response to the pressure from foreign donors and civil society representatives. According to Zaman, Rahman and Alim, the ACC was created in 2004 by the government "reluctantly, rather than out of genuine political will" in response to "a combination of civil society demands and pressure from international donors." 51

The second reason was that the ACC had unwisely decided to rehire many of the BAC's ineffective personnel, including those officers who were accused of corruption. According to M. Hafuzuddin Khan, a member of the screening committee responsible for reviewing the profile of former BAC officers, many BAC personnel were absorbed into the ACC even though their reputation and efficiency were "highly questionable." 52 Consequently, the ACC inherited the BAC's onerous baggage "when it sweepingly absorbed its staff without due scrutiny, and therefore sowed the seeds of [the] ACC's

48 Basir Ahmed, 'Combating Corruption: The Role of the Bureau of Anti-Corruption (BAC) in Bangladesh' (Masters Programme in Asian Studies, Centre for East and Southeast Asian Studies, Lund University 2006) 27.

49 Ibid, 28.

50 Aqil Shah, 'South Asia' in Robin Hodess (ed), Global Corruption Report 2001 (Transparency International 2001) 44.

51 Iftekhar Zaman, Sydur Rahman and Abdul Alim, 'Bangladesh' in Jana Kotalik and Diana Rodriguez (eds), Global Corruption Report 2006 (Pluto Press 2006) 127.

52 Aminuzzaman and Khair (n 44) 176-177.

Page $\mid 106$ 
deficit of efficiency and integrity" ${ }^{, 53}$ and also 20,000 unsolved corruption cases. ${ }^{54}$

In sum, the ACC has inherited and continued the BAC's role as an attack dog against the incumbent government's political opponents instead of performing the desired role as an independent watchdog. ${ }^{55}$

\section{ACC's lack of expertise in investigation and prosecution}

Bangladesh's national integrity system was evaluated in 2003 and an important finding was that the standard of the BAC's investigation officers and their work methods were "not up to the mark." ${ }^{56}$ A key informant interviewed by Shadhan Kumar Das has attributed the ACC's weak legal and prosecution capacity to the lack of specialised training: "There are many staff [members] aged more than 50 [years old] assigned in the investigation. They do not have energy, skill, courage and patience to handle such cases." ${ }^{, 57}$ In its June 2011 evaluation of Bangladesh's anti-corruption efforts, the Norwegian Agency for Development Cooperation (NORAD) found that the ACC "showed a serious lack of capacity in its execution of the challenge to investigate and to prosecute" and its "expansion of activities was over-ambitious" and "unsupported by the necessary capacity to channel the work with complete competence." ${ }^{58}$

Similarly, the 2014 assessment of Bangladesh's national integrity system has indicated that the ACC lacked officers with credibility and expertise at the field level and those officers recruited were inadequately trained. The ACC's legal and prosecution capacity was also weak and needed improvement. ${ }^{59} \mathrm{~A}$ more recent evaluation revealed that the ACC officers lacked expertise in investigating corruption cases and they usually took three years to complete an investigation. ${ }^{60}$

The 2018 assessment found that the ACC had the lowest average score of 44 per cent for the nine indicators on detection, investigation and prosecution.${ }^{61}$ More specifically, a low score was given for the ACC's investigation and prosecution expertise because its investigation officers (IOs) did not have the necessary expertise to deal with the issues of converting property, banking sector corruption, and detention of property.

53 Iftekharuzzaman, 'Anti-Corruption Commission: How can it be truly effective?' The Daily Star (Dhaka, 15 February 2019).

54 Tarana Begum and Nurul Huda Sakib, 'Combating Corruption in Bangladesh: Role of the AntiCorruption Commission' in Al Masud Hasanuzzaman and Shamsul Alam (eds), Political Management in Bangladesh (A.H. Development Publishing House 2010) 254.

55 Jon S.T. Quah, 'Combating Corruption in Asian Countries: Learning from Success and Failure' (2018) 147 Daedalus 212-213.

56 M. Farid, Shamila Mahbub and Muhammad Anwarul Amin, National Integrity Systems Country Study Report Bangladesh 2003 (Transparency International 2003) 41.

57 Shadhan Kumar Das, 'Anti-Corruption Commission of Bangladesh: Diagnosis of a Fading Hope' (Research paper prepared in partial fulfilment of the Master of Development Studies, International Institute of Social Sciences 2013) 26-27.

58 Norwegian Agency for Development Cooperation, Joint Evaluation of Support to Anti-Corruption Efforts: Bangladesh Country Report (2011) 31.

59 Aminuzzaman and Khair (n 44) 177.

60 Aminuzzaman, Akram and Islam (n 27) 36-37.

61 Shammi Laila Islam and Shahzada M. Akram, Anti-Corruption Agency Strengthening Initiative Assessment of Bangladesh Anti-Corruption Commission 2018 (Transparency International Bangladesh 2020) 68. 
Newly recruited IOs who were not familiar with the procedure for filing corruption cases made procedural mistakes. On the other hand, older ACC officers lack the knowledge and skills to investigate money laundering cases. ${ }^{62}$

In view of the above criticisms of the ACC's lack of expertise in investigating and prosecuting corruption cases, it is not surprising that Transparency International Bangladesh has described the ACC as "the most unenviable institution" in Bangladesh because "it has been ridiculed in the parliament and outside" and the "degree of professional excellence, integrity and credibility of its staff has been criticised." The ACC has also failed to address the "integrity, transparency and capacity of its staff" and has not adopted a code of conduct and manual for internal governance for its personnel. ${ }^{63}$

Governments usually rely on codes of conduct to guide and control the behaviour of public officials by providing them with an indication of the desired ethical values, guidelines for their behaviour as well as the punishment for violating these principles. ${ }^{64}$ While codes of conduct are not "a cure-all for all violations of the public trust," they "provide preventive medicine against the malady of unethical conduct and a distasteful dose of medicine for an employee who contracts the disease." ${ }^{65}$ A code of conduct provides new recruits to the civil service with a guide for evaluating the propriety of their own actions and the actions of other individuals. Hence, it is troubling and puzzling why the Bangladesh ACC has operated for the past 16 years without a code of conduct for its personnel, especially when its function is to curb corruption in both the public and private sectors. This means that the ACC's personnel have been performing their duties since November 2004 without the benefit of having a code of conduct to prevent them from behaving unethically. Indeed, the absence of a code of conduct for the ACC's personnel should be rectified because it sends the wrong signal not only to them but also to other public officials and citizens in Bangladesh.

An analysis of the 70,464 corruption complaints received by the ACC during 20142018 in Table 6 shows that only 6,138 complaints ( 8.7 per cent) were screened by it for enquiry, 2,771 complaints (3.9 per cent) were referred to other ministries for action, and no action was taken for 61,555 complaints (87.4 per cent), which were filed. With the ACC's heavier workload and increased number of vacancies, its output has decreased with the total number of investigations reduced from 3,428 in 2016 to 1,519 in 2017, and the number of investigations completed also decreased from 2,271 to 489 during the same period. ${ }^{66}$

\section{Table 6: Corruption Complaints Received and Dealt by the ACC, 2014-2018}

62 Ibid, 52.

63 Iftekharuzzaman, 'The most unenviable institution' The Daily Star (Dhaka, 18 March 2013).

64 Alan Lawton, Julie Rayner and Karin Lasthuizen, Ethics and Management in the Public Sector (Routledge 2013) 98.

65 Kenneth Kernaghan, Ethical Conduct Guidelines for Government Employees (Institute of Public Administration of Canada 1975) 4-5.

66 Bangladesh ACC, Annual Report 2016 (2017) 26 and Bangladesh ACC, Annual Report 2018 (2019) 26.

Page $\mid 108$ 
Minimising Corruption in Bangladesh

\begin{tabular}{|l|l|l|l|l|}
\hline Year & $\begin{array}{c}\text { No. of complaints } \\
\text { received }\end{array}$ & $\begin{array}{c}\text { No. of complaints } \\
\text { screened for } \\
\text { enquiry }\end{array}$ & $\begin{array}{c}\text { No. of complaints } \\
\text { sent to ministries }\end{array}$ & $\begin{array}{c}\text { No. of complaints } \\
\text { filed }\end{array}$ \\
\hline 2014 & 12,500 & $1,689(13.5 \%)$ & $237(1.9 \%)$ & $10,574(84.6 \%)$ \\
\hline 2015 & 10,415 & $1,240(11.9 \%)$ & $165(1.6 \%)$ & $9,010(86.5 \%)$ \\
\hline 2016 & 12,990 & $1,007(7.8 \%)$ & $588(4.5 \%)$ & $11,395(87.7 \%)$ \\
\hline 2017 & 17,953 & $937(5.2 \%)$ & $377(2.1 \%)$ & $16,639(92.7 \%)$ \\
\hline 2018 & 16,606 & $1,265(7.6 \%)$ & $1,404(8.5 \%)$ & $13,937(83.9 \%)$ \\
\hline Total & 70,464 & $6,138(8.7 \%)$ & $2,771(3.9 \%)$ & $61,555(87.4 \%)$ \\
\hline
\end{tabular}

Sources: Bangladesh ACC, Annual Report 2017 (2018) 22 and Bangladesh ACC, Annual Report 2018 (2019) 21.

The clearest manifestation of the ACC's limited expertise in prosecution is the absence of its own prosecution unit 16 years after its formation. Section 33 of the ACC Act of 2004 has stipulated that the ACC should establish:

1. Its own prosecution unit consisting of the number of prosecutors required to conduct the cases to be investigated by the commission under this law and to be tried before the special judge.

2. The conditions of appointment and service of the prosecutors shall be determined by rules.

3. Until the appointment of its own prosecutors under this law, lawyers temporarily appointed by the commission shall conduct its cases.

4. Prosecutors appointed under this section shall be deemed to be public prosecutors (emphasis added).

The ACC has not explained in its annual reports why it has not established its own prosecution unit as required by section 33 during the past 16 years and continues to rely on the "temporary appointment" of lawyers on contract to serve as public prosecutors instead of filling the 10 sanctioned positions of prosecutors. ${ }^{67}$ The ACC employed 28 lawyers to handle its prosecution cases in $2018 .^{68}$ The 2018 assessment of the ACC mentioned above also found that the lawyers hired by the ACC were not qualified and lacked the necessary skills and competence to be public prosecutors. ${ }^{69}$ Consequently, it is not surprising that the ACC's conviction rate has varied from 37 per cent in 2015 to 68 per cent in $2017 . .^{70}$

\section{CONCLUSION}

The preceding analysis shows that Bangladesh has established the ACC as a Type A

67 Bangladesh ACC, Annual Report 2016 (2017) 31.

68 Bangladesh ACC, Annual Report 2018 (2019) 38.

69 Islam and Akram (n 61) 52.

70 Bangladesh ACC, Annual Report 2018 (2019) 34. 
ACA in 2004 to emulate the formation of the CPIB in Singapore in 1952 and the ICAC in Hong Kong in 1974. However, unlike the CPIB and ICAC, the ACC has to date failed to perform the desired role of an independent watchdog because of the lack of political will of both the AL and BNP governments which have used the ACC as an attack dog against their political opponents when they are in power. Furthermore, the ACC is also a paper tiger because both governments have not provided it with the necessary budget and personnel to enforce the anti-corruption laws impartially without political interference.

Table 7 confirms that the ACC is ineffective in minimising corruption because Bangladesh has performed poorly on the CPI from 2012-2019 with its CPI scores varying from 25 in 2014 and 2015 to 28 in 2017. Similarly, Table 7 also shows that Bangladesh's percentile rank on the World Bank's control of corruption indicator has declined from 21.33 in 2012 to 16.35 in 2019. Does Bangladesh's consistently weak performance on both the CPI and the control of corruption indicator during 2012-2019 mean that minimising corruption in Bangladesh is an impossible dream?

Learning from the successes of Singapore and Hong Kong in combating corruption, ${ }^{71}$ policy-makers in Bangladesh will only succeed in combating corruption if both the AL and BNP political leaders have sufficient political will to relinquish their reliance on the ACC as an attack dog against each other when they are in power. However, if these political leaders persist in using the ACC as an attack dog, the only alternative avenue for change is for concerned Bangladeshi citizens to elect other competent and honest persons to political office who are accountable for their actions. ${ }^{72}$

Table 7: Bangladesh's Performance on the CPI and Control of Corruption, 2012-2019

\begin{tabular}{|c|c|c|c|c|}
\hline \multirow{2}{*}{ Year } & \multicolumn{2}{|c|}{ Corruption Perceptions Index } & \multicolumn{2}{c|}{ Control of Corruption } \\
\cline { 2 - 5 } & Rank & Score & Score & Percentile rank \\
\hline 2012 & $144^{\text {th }} / 176$ & 26 & -0.85 & 21.33 \\
\hline 2013 & $136^{\text {th }} / 177$ & 27 & -0.89 & 20.85 \\
\hline 2014 & $145^{\text {th }} / 175$ & 25 & -0.89 & 19.23 \\
\hline 2015 & $139^{\text {th }} / 168$ & 25 & -0.81 & 22.12 \\
\hline 2016 & $145^{\text {th }} / 176$ & 26 & -0.86 & 18.75 \\
\hline 2017 & $143^{\text {rd }} / 180$ & 28 & -0.83 & 19.23 \\
\hline 2018 & $149^{\text {th }} / 180$ & 26 & -0.91 & 16.83 \\
\hline
\end{tabular}

71 For details of Singapore's and Hong Kong's effective anti-corruption strategies, see Jon S.T. Quah, 'Singapore's Effective Anti-Corruption Recipe: Lessons for Other Countries' in Adam Graycar (ed), Handbook on Corruption, Ethics and Integrity in Public Administration (Edward Elgar 2020) 360-376 and Ian Scott and Ting Gong, Corruption Prevention and Governance in Hong Kong (Routledge 2019).

72 Jon S.T. Quah, 'The Critical Importance of Political Will in Combating Corruption in Asian Countries' (2015) 18 Public Administration and Policy 15-17.

Page | 110 


\begin{tabular}{|l|l|l|l|l|}
\hline 2019 & $146^{\text {th }} / 180$ & 26 & -0.99 & 16.35 \\
\hline
\end{tabular}

Sources: Transparency International, Corruption Perceptions Index 2019 (2020) and World Bank 'Worldwide Governance Indicators, 2012-2019' (2020)

<http://info.worldbank.org/governance/wgi/Home/Reports> accessed 4 November 2020.

Apart from not relying on the ACC as an attack dog against their political opponents, Bangladeshi political leaders must also enhance the ACC's capacity by improving its officers' expertise in investigating corruption cases and avoid delaying further the formation of its own prosecution unit as required by section 33 of the ACC Act of 2004. The refusal of the AL and BNP governments since 2004 to establish a prosecution unit within the ACC is an indictment of their weak political will in combating corruption in Bangladesh. The public image of the ACC as a paper tiger can only be rectified if the incumbent government increases its low per capita expenditure of US $\$ 0.64$ and improves its unfavourable staff-population ratio of 1:169,741 in 2016 (see Table 5) by providing the ACC with the necessary budget and personnel.

Finally, minimising corruption in Bangladesh will remain an impossible dream unless its policy-makers also address the causes of corruption by introducing reforms to improve the low salaries of civil servants, to reduce red tape and the opportunities for corruption, to increase the probability of detecting and punishing those persons found guilty of corruption offences, and to reduce the widespread influence of gift-giving and tadbir among civil servants and the public.

In short, corruption in Bangladesh can only be minimised if its political leaders initiate reforms to address the causes of corruption and replace their penchant for using the ACC as an attack dog against their political opponents with the reliance instead on the ACC as an independent watchdog to enforce the anti-corruption laws impartially, regardless of the position, status or political affiliation of those persons being investigated for corruption offences. 